\title{
EFEKTIVITAS PELAKSANAAN UPAYA PEMBINAAN BAGI NARAPIDANA DI LEMBAGA PEMASYARAKATAN KELAS IIA KARAWANG
}

\author{
Abdul Kholiq \\ abdulkholiq@ubpkarawang.ac.id \\ Universitas Buana Perjuangan Karawang
}

\begin{abstract}
Abstrak
Pentingnya pelaksanaan pembinaan pada narapidana dalam upaya mengembalikan stigma negatif agar menjadi masyarakat yang baik sangatlah penting dilakukan, tidak hanya bersifat materiil atau spiritual saja melainkan keduanya harus berjalan dengan seimbang. Penelitian ini bertujuan mengetahui efektivitas pelaksanaan pembinaan terhadap narapidana oleh petugas Lembaga Pemasyarakatan Kelas IIA Karawang, serta menemukan faktor-faktor penghambat/kendala dalam pelaksanaan pembinaan tersebut. Metode penelitian yang digunakan adalah metode yuridis-empiris, dengan mengedepankan wawancara langsung di lapangan (field research). Pelaksanaan pembinaan bagi narapidana diatur secara teknis dalam Peraturan Pemerintah Nomor 31 Tahun 1999 tentang Pembinaan dan Pembimbingan Warga Binaan Pemasyarakatan. Dari ketentuan ini, dapat dijadikan ukuran dalam pelaksanaan pembinaan tersebut dalam berjalan dengan efektif atau sebaliknya. Pertimbangan upaya pelaksanaan pembinaan akan menjadikan bekal bagi narapidana setelah menjalani hukuman dalam lembaga dan selanjutnya kembali pada kehidupan masyarakat (resosislisasi).
\end{abstract}

Kata Kunci : efektivitas, pembinaan, narapidana

\begin{abstract}
The importance of implementing guidance to prisoners in an effort to restore negative stigma to be a good society is very important, not only material or spiritual but both must run in a balanced way. This study aims to determine the effectiveness of the implementation of coaching of prisoners by Class IIA Penitentiary officers in Karawang, as well as discovering inhibiting factors / constraints in the implementation of the coaching. The research method used is a juridical-empirical method, by prioritizing direct interviews in the field (field research). The implementation of guidance for prisoners is technically regulated in Government Regulation Number 31 of 1999 concerning Guidance and Guidance of PrisonAssisted Citizens. From this provision, it can be used as a measure in the implementation of the coaching in running effectively or vice versa. Consideration of the efforts to carry out coaching will provide provisions for prisoners after serving their sentence in the institution and subsequently returning to community life (resosialization).
\end{abstract}

Keywords : effectiveness, coaching, convict 


\section{EFEKTIVITAS PELAKSANAAN UPAYA PEMBINAAN BAGI NARAPIDANA DI LEMBAGA PEMASYARAKATAN KELAS IIA KARAWANG : Abdul Kholiq}

\section{PENDAHULUAN}

Lembaga Pemasyarakatan merupakan institusi atau lembaga dari sub sistem peradilan pidana yang mempunyai fungsi strategis sebagai pelaksanaan penjara dan sekaligus sebagai tempat untuk proses pembinaan dan pembimbingan terhadap narapidana sebagaimana yang telah diamanatkan oleh Undang - Undang Nomor 12 Tahun 1995 tentang Pemasyarakatan. Di dalam penjelasan Undang - Undang Pemasyarakatan telah dijelaskan bahwa sebelumnya di Indonesia dikenal dengan sistem pemenjaraan yang menekankan pada upaya balas dendam dan penjeraan, sehingga institusi yang dipergunakan sebagai tempat pembinaan adalah rumah penjara. Selanjuntya bentuk rumah penjara tersebut secara berangsur - angsur dipandang sebagai suatu sistam dan sarana yang tidak sejalan dengan konsep rehabilitasi dan reintegrasi sosial, agar narapidana menyadari dan tidak legi berkehendak untuk melakukan tindak pidana dan menjadi warga masyarakat yang bertanggung jawab bagi diri, keluarga dan lingkungannya.

Upaya pelaksanaan pembinaan ini tentu akan bergantung pada situasi dan kondisi yang ada pada lembaga pemasyarakatan, karena latar belakang yang dimilikinya berbeda-beda. Dalam penelitian ini yang akan dilakukan di Lembaga Pemasyarakatan Kelas IIA Karawang, maka perlu diketahui kondisi yang terjadi di lembaga tersebut. Lembaga Permasyarakatan Kelas IIA Karawang merupakan institusi dibawah wewenang dan wilayah hukum Kanwil Hukum dan HAM Provinsi Jawa Barat. Secara keseluruhan jumlah lembaga atau institusi yang berada di bawah wewenang Kanwil Hukum dan HAM Provinsi Jawa Barat adalah 32 lembaga. Dari jumlah 32 lembaga tersebut bahwa diantaranya sebanyak 23 lembaga pemasyarakat telah melebihi dari kapasitas yang tersedia, dan sejumlah 9 lembaga pemasyarakat masih mencukupi dengan jumlah penghuni tersebut. Melihat dari data - data tersebut tentu akan menjadi permsalahan dari proses pembinaan 


\section{EFEKTIVITAS PELAKSANAAN UPAYA PEMBINAAN BAGI NARAPIDANA DI LEMBAGA PEMASYARAKATAN KELAS IIA KARAWANG : Abdul Kholiq}

karena terjadinya kelebihan jumlah penghuni (over capacity). Salah pembinaan tersebut tidak akan mampu berjalan secara optimal dan maksimal.

Data Kapasitas Penghuni di LP Kelas IIA Karawang Tahun 2017 ${ }^{1}$

\begin{tabular}{|r|l|r|r|r|r|r|r|r|}
\hline No & Bulan & $\begin{array}{c}\text { Jumlah } \\
\text { Tahanan }\end{array}$ & $\begin{array}{c}\text { Jumlah } \\
\text { Narapidana }\end{array}$ & $\begin{array}{c}\text { Total } \\
\text { Jumlah }\end{array}$ & $\begin{array}{c}\text { Kapasitas } \\
\text { LP }\end{array}$ & $\begin{array}{c}\text { Jumlah } \\
\text { kelebihan }\end{array}$ & $\begin{array}{c}\text { Kapasitas } \\
\mathbf{1 0 0 \%}\end{array}$ & $\begin{array}{c}\text { Over } \\
\text { capacity } \\
\%\end{array}$ \\
\hline 1 & Januari & 243 & 800 & 1043 & 590 & 453 & 177 & 77 \\
\hline 2 & Februari & 246 & 800 & 1046 & 590 & 456 & 177 & 77 \\
\hline 3 & Maret & 239 & 796 & 1035 & 590 & 445 & 175 & 75 \\
\hline 4 & April & 253 & 792 & 1045 & 590 & 455 & 177 & 77 \\
\hline 5 & Mei & 269 & 791 & 1060 & 590 & 470 & 180 & 80 \\
\hline 6 & Juni & 275 & 808 & 1083 & 590 & 493 & 184 & 84 \\
\hline 7 & Juli & 260 & 826 & 1086 & 590 & 496 & 184 & 84 \\
\hline 8 & Agustus & 258 & 814 & 1072 & 590 & 482 & 182 & 82 \\
\hline 9 & September & 261 & 808 & 1069 & 590 & 479 & 181 & 81 \\
\hline 10 & Oktober & 281 & 803 & 1084 & 590 & 494 & 184 & 84 \\
\hline 11 & Nopember & 259 & 838 & 1097 & 590 & 507 & 186 & 86 \\
\hline 12 & Desember & 283 & 836 & 1119 & 590 & 529 & 190 & 90 \\
\hline
\end{tabular}

satunya di Lembaga Pemasyarakatan

Kelas IIA Karawang terjadi kelebihan kapasitas tersebut. Hal ini berdasarkan data yang disampaikan oleh Sistem Database Pemasyarakatan Direktorat Jenderal Pemasyarakatan Kementerian Hukum dan HAM Republik Indonesia (website: http://smslap.ditjenpas.go.id).

Berdasarkan pada data diatas, terlihat jumlah dari penghuni Lembaga Pemasyarakatan Kelas IIA Karawang melebihi dari kuota atau kapasitas yang menjadi batas penghuni secara normal. Bila dihubungkan dengan proses pembinaan dan pembimbingan dari petugas pemasyarakatan, maka upaya
Dikarenakan ketersediaan dari sumber daya manusia yang dimiliki Lembaga Pemasyarakatan Kelas IIA Karawang yang tidak sebanding dengan rasio jumlah penghuni lembaga tersebut. Fenomena tersebut jelas bukan merupakan faktor kondusif bagi suatu proses pembinaan narapidana yang muaranya mencapai tujuan pemidanaan antara lain reintegrasi sosal dan dapat kembali diterima amsyarakat serta dapat menjalankan perannya sebagai anggota masyarakat secara umum. Dengan demikian, penelitian ini bermaksud untuk mengetahui sejauh mana efektivitas pelaksanaan upaya 


\section{EFEKTIVITAS PELAKSANAAN UPAYA PEMBINAAN BAGI NARAPIDANA DI LEMBAGA PEMASYARAKATAN KELAS IIA KARAWANG : Abdul Kholiq}

pembinaan bagi narapidana di Lembaga Pemasyarakatan Kelas IIA Karawang.

Pentingnya dalam pelaksanaan pembinaan pada narapidana dalam upaya mengembalikan stigma negatif agar menjadi masyarakat yang baik sangatlah penting dilakukan, tidak hanya bersifat materiil atau spiritual saja melainkan keduanya harus berjalan dengan seimbang. Hal ini merupakan pokok dalam menunjang narapidana mudah dalam menjalani kehidupannya setelah selesai menjalani masa hukuman atau pidananya. Pembinaan dan bimbingan yang dilakukan oleh Lembaga Pemasyarakatan Kelas IIA Karawang diharapkan mampu membentuk kepribadian serta mental pada diri narapidana yang telah mendapatkan stiga buruk oleh masyarakat menjadi berubah kearah yang normal dan sesuai norma serta kaidah hukum yang berlaku. Oleh karena itu, perlu adanya kerjasana dari komponen - komponen yang menunjang keberhasilan proses pembinaan bagi narapidana yaitu petugas Lembaga Pemasyarakatan, narapidana dan masyarakat.

\section{PERMASALAHAN}

Berdasarkan latar belakang diatas, maka hal - hal yang dijadikan permasalahan adalah :

1. Bagaimana efektivitas pelaksanaan pembinaan bagi narapidana di Lembaga Pemasyarakatan Kelas IIA Karawang?

2. Apa faktor-faktor penghambat atau kendala dalam pelaksanaan pembinaan bagi narapidana di Lembaga Pemasyarakatan Kelas IIA Karawang?

\section{METODE PENELITIAN}

Jenis penelitian ini menggunakan penelitian hukum yuridis empiris (yuridis sosiologis) yaitu penelitian yang dilakukan untuk mengevaluasi keterkaitan aspek-aspek empiris. ${ }^{1}$

${ }^{1}$ Ashofa, Burhan, 2007, Metode Penelitian Hukum, Jakarta : Rineka Cipta, hal 34 


\section{EFEKTIVITAS PELAKSANAAN UPAYA PEMBINAAN BAGI NARAPIDANA DI LEMBAGA PEMASYARAKATAN KELAS IIA KARAWANG : Abdul Kholiq}

Dengan metode penelitian yang dilakukan dalam penelitian ini diawali dengan adanya pengumpulan data awal metode deskriptif. Sumber data yang diperlukan dalam penelitian ini meliputi data primer yang merupakandata pokok dalam penelitian yang berasal dari responden dan informan yakni petugas Lembaga Pemasyarakatan Kelas IIA Karawang dan warga binaan di Lapas Kelas IIA Karawang. Sedangkan data sekunder diperoleh dari bahan- bahan peraturan perundang-undangan sebagai penunjang data primer yakni Undang Undang Nomor 12 Tahun 1995 tentang Pemasyarakatan dan Peraturan Pemerintah Nomor 31 Tahun 1999 tentang Pembinaan dan Pembimbingan Warga Binaan Pemasyarakatan. Teknik pengumpulan data dilakukan dengan melalui tahapan wawancara, observasi dan studi kepustakaan. Selanjutnya metode analisis yang dilakukan dalam penelitian ini diantaranya pengmpulan data, penyajian data dan penarikan kesimpulan.

\section{PEMBAHASAN}

\section{A. Efektivitas}

Pelaksanaan

Pembinaan Bagi Narapidana

Di Lembaga Pemasyarakatan

\section{Kelas IIA Karawang}

Lembaga Pemasyarakata Kelas

IIA Karawang merupakan lingkup dari Kantor Wilayah Kementerian Hukum dan Hak Asasi Manusia Jawa Barat yang terletak di Jl. Surotokunto No.110, Warungbambu, Kecamatan Karawang Timur., Kabupaten Karawang, Jawa Barat. Berkaitan dengan upaya pembinaan yang dilakukan oleh Lembaga Pemasyarakatan Kelas IIA Karawang terhadap narapidana/warga binaan didasarkan pada Keputusan Menteri Kehakiman Republik Indonesia Nomor: M.02-PK.04.10 Tahun 1990 tentang Pola Pembinaan Narapidana dan Tahanan. Bentuk pembinaan sebagaimana diatur dalam peraturan tersebut meliputi 2 (dua) hal diantaranya: (a) pembinaan kepribadian; dan (b) pembinaan kemandirian. Adapun wujud dari pembinaan kepribadian meliputi pembinaan kesadaran beragama, pembinaan berbangsa dan bernegara, 


\section{EFEKTIVITAS PELAKSANAAN UPAYA PEMBINAAN BAGI NARAPIDANA DI LEMBAGA PEMASYARAKATAN KELAS IIA KARAWANG : Abdul Kholiq}

pembinaan kemampuan intelektual, pembinaan kesadaran hukum, dan pembinaan mengintegrasikan diri dengan masyarakat. Sedangkan wujud dari pembinaan kemandirian meliputi program keterampilan untuk mendukung usaha mandiri, keterampilan untuk mendukung usaha kecil, keterampilan yang dikembangkan sesuai bakat para narapidana, keterampilan untuk mendukung usaha industri atau kegiatan pertanian (perkebunan) dengan menggunakan teknologi madya atau teknologi tinggi.

Upaya yang ditempuh dalam orientasi pelaksanaan pembinaan terhadap narapidana atau warga binaan pemasyarakatan di lembaga pemasyarakatan dimaksudkan untuk memberikan bekal dan membentuk sikap mental narapidana agar menginsyafi segala perbuatan dan kesalahannya yang telah terjadi sebelumnya dalam kehidupannya. Selanjutnya tidak mengulangi tindak pidana, memperbaiki diri sendiri dan menjadi manusia yang berbudi luhur ketika kembali dalam lingkungan masyarakat (resosialisasi).

Pelaksanaan pembinaan yang dilakukan di lembaga pemasyarakatan memerlukan peran dan kerjasama dari elemen - elemen yang terdapat dalam lembaga tersebut seperti petugas lembaga pemasyarakatan, warga binaan pemasyarakatan serta keluarga atau masyarakat dalam mendukung kegiatan yang ditujukan kepada penghuni lembaga pemasyarakatan. Karenanya pelaksanaan program pembinaan tersebut memerlukan keterpaduan terutama antar narapidana atau warga binaan pemasyarakatan yang bersangkutan, petugas hukum yang mempunyai kepentingan dalam hal pembinaan serta masyarakat umum yang akan menerima kembali warga binaan pemasyarakatan dikemudian dalam kehidupan masyarakat seperti sebelumnya.

Dalam pelaksanaan pembinaan bagi narapidana atau warga binaan pemasyarakatan, terapat 3 (tiga) hal penting yang harus terlebih dahulu dipahami agar pelaksanaan pembinaan tersebut dalam maksimal dan sesuai 


\section{EFEKTIVITAS PELAKSANAAN UPAYA PEMBINAAN BAGI NARAPIDANA DI LEMBAGA PEMASYARAKATAN KELAS IIA KARAWANG : Abdul Kholiq}

dengan harapan bagi narapidana, petugas lembaga pemasyarakatan dan masyarakat secara umum yakni :

1) bahwa proses pemasyarakatan diatur dan dikelola dengan semangat pengayoman dan pembinaan bukan pembalasan dan penjaraan;

2) bahwa proses pemasyarakatan mencakup pembinaan narapidana di dalam dan diluar lembaga (intramural dan etramural); dan

3) proses pemasyarakatan memerlukan partisipasi, keterpaduan dari para petugas pemasyarakatan pada narapidana dan anak didik pemasyarakatan serta anggota masyarakat umum. ${ }^{2}$

Beranjak dari pernyataan diatas, maka sebelum petugas lembaga pemasyarakatan melakukan proses dari pembinaan terhada narapidana terlebih dahulu mengetahui dan memahami metode yang dapat dilakukan dan diharapkan program pembinaan dapat berjalan secara efektif dan efisien. Serta dengan harapan lain bahwa tujuan- tujuan dari pembinaan seperti menyadarkan narapidana sehingga menjadi bak dalam kehidupannya dimasyarakat (resosialisasi) dapat tercapai. Metode - metode yang digunakan bagi petugas Lembaga Pemasyarakatan Kelas IIA Karawang dalam melaksanakan pembinaan dan pembimbingan terhadap narapidana adalah sebagai berikut :

a) Metode Top Down Approach dan Bottom Up Approach

Pembinaan top down approach adalah bentuk pembinaan dengan melakukan pembinaan dari atas ke bawah. Model pembinaan ini diterapkan oleh patugas lembaga pemasyarakatan terhadap narapidana sesuai dengan kemampuan dan kepribadian narapidana. Sedangkan, pembinaan bottom up approach merupakan pendekatan yang dilakukan dari bawah ke atas. Dalam pendekatan ini,

\footnotetext{
${ }^{2}$ R Soegondo dalam Marlina, 2011, Hukum Penitensier, Bandung : Refika Aditama, hal 124-125
} 


\section{EFEKTIVITAS PELAKSANAAN UPAYA PEMBINAAN BAGI NARAPIDANA DI LEMBAGA PEMASYARAKATAN KELAS IIA KARAWANG : Abdul Kholiq}

narapidana diperbolehkan untuk memilih atau menentukan jenis jenis dari pembinaan yang dikehendaki dan sesuai dengan bakat narapidana serta yang disediakan oleh Lembaga Pemasyarakatan Kelas IIA Karawang.

b) Metode Gabungan antara Perorangan (personal) dan Kelompok (groups)

Pembinaan dengan mempergunakan metode gabungan ini diterapkan dengan menyesuaikan kemampuan dan kepribadian narapidana. Setiap narapidana memiliki latar belakang pendidikan, latar belakang kehidupan masyarakat, sikap dan tingkah laku serta bakat dan minat yang berbeda-beda, sehingga mempengaruhi kemampuan serta kepribadian narapidana masingmasing. Berdasarkan hal tersebut, pembinaan yang dilakukan terhadap narapidana tidak sama satu dengan yang lain. c) Pembinaan yang diberikan Bersifat Persuasif dan Edukatif

Pembinaan yang dilakukan oleh petugas bertujuan untuk mengubah perilaku narapidana melalui keteladanan dan memperlakukan mereka secara adil. Dengan pembinaan semacam itu, diharapkan narapidana dapat menunjukkan sikapnya yang terpuji. Disamping itu petugas lembaga pemasyarakatan juga menganggap bahwa narapidana merupakan bagian dari masyarakat yang memiliki harga diri dan martabat seperti manusia yang lainnya.

d) Pembinaan dilakukan Secara Sistematis dan Keberlanjutan Pembinaan ini mengandung pengertian bahwa pembinaan yang dilakukan setiap hari kepada narapidana mempunyai keterikatan satu dengan yang lainnya sehingga narapidana dapat sedikit demi sedikit mengerti mengenai materi yang 


\section{EFEKTIVITAS PELAKSANAAN UPAYA PEMBINAAN BAGI NARAPIDANA DI LEMBAGA PEMASYARAKATAN KELAS IIA KARAWANG : Abdul Kholiq}

disampaikan. Penyampaian materi oleh petugas disampaikan sesuai dengan kemampuan masing-masing narapidana.

e) Pembinaan dilakukan dengan Interaksi Langsung (Petugas dan narapidana) Bersifat

Kekeluargaan

Pembinaan ini dilakukan misalnya pada saat petugas memberi bimbingan konseling pada narapidana. Dalam memberikan bimbingan, petugas tidak memandang narapidana sebagai seorang yang bersalah, tetapi ia menganggap narapidana sebagai bagian dari masyarakat yang memiliki Hak asasi dan harus dihargai. Petugas menganggap narapidana sebagai bagian dari anggota keluarga. Dengan adanya metode ini narapidana dapat menyampaikan keluhan dan masalah yang dihadapi pada petugas dengan terbuka.

Perwujudan dari sistem pembinaan terhadap narapidana tetap mengedepankan hak-hak bagi narapidana selama menjalani hukuman pidana di lembaga pemasyarakatan, hal ini diatur dalam Pasal 14 UndangUndang Nomor 12 Tahun 1995 tentang Pemasyarakatan, sebagai berikut :

(1) Narapidana berhak :

a. melakukan ibadah sesuai dengan agama atau kepercayaan;

b. mendapat perawatan, baik perawatan rohani maupun jasmani;

c. mendapatkan pendidikan dan pengajaran;

d. mendapatkan pelayanan kesehatan dan makanan yang layak;

e. menyampaikan keluhan;

f. mendapatkan bahan bacaan dan mengikuti siaran media massa lainnya yang tidak terlarang;

g. mendapatkan upah atau premi atas pekerjaan yang dilakukan;

h. menerima kunjungan keluarga penasihat hukum atau orang tertentu lainnya;

i. mendapatkan pengurangan masa pidana (remisi);

j. mendapatkan kesempatan berasimiliasi termasuk cuti, mengunjungi keluarga;

k. mendapatkan pembebasan bersyarat; 


\section{EFEKTIVITAS PELAKSANAAN UPAYA PEMBINAAN BAGI NARAPIDANA DI LEMBAGA PEMASYARAKATAN KELAS IIA KARAWANG : Abdul Kholiq}

1. mendapatkan cuti menjelang bebas; dan

m. mendapatkan hak-hak lain sesuai dengan peraturan perundangundangan yang berlaku.

Dari beberapa hak diatas, peneliti melakukan wawancara dengan salah satu narapidana (Andriyana/29 tahun/ laki-laki) berkaitan dengan upaya pelayanan dan pembinaan yang diberikan oleh petugas Lembaga Pemasyarakatan Kelas IIA Karawang, sebagai berikut :

"petugas lapas telah
menyampaikan dan
memberitahukan kepada para
narapidana (napi) mengenai hak-
hak yang diberikan selama
menghuni lapas. Petugas juga
menyebutkan fasilitas-fasilitas
yang ada untuk mendukung
pelaksanaan hak-hak tersebut
seperti masjid (tempat ibadah),
tempat olahraga, area berkunjung
keluarga, dan lain sebagainya".3

Berdasarkan hasil wawancara diatas, dapat diketahui bahwa bagi seorang narapidana atau warga binaan pemasyarakatan akan mendapatkan

\footnotetext{
${ }^{3}$ Hasil wawancara peneliti bersama narapidana Lembaga Pemasyarakatan Kelas IIA Karawang
}

penyampaian hal-hal yang menjadi hak-hak serta kewajiban baginya. Upaya tersebut dilakukan sebagai sarana untuk memberikan pelayanan yang baik, karena setiap narapidana yang pertama kali menghuni tidak mendapatkan informasi yang diketahui kecuali oleh petugas lembaga pemasyarakat tersebut menyampaikannya.

Dalam kesempatan yang lain juga, peneliti melakukan wawancara kepada petugas Lembaga Pemasyarakatan Kelas IIA Karawang (Bapak Darsono, SH / Pengelola Pembinaan Kepribadian) mengenai pelaksanaan fungsi dan pelayanan serta bentuk-bentuk pembinaan yang diberikan kepada warga binaan pemasyarakatan, beliau menyampaikan argumennya sebagai berikut :

"Lembaga Pemasyarakatan (lapas) Kelas IIA Karawang telah melaksanakannya sesuai dengan peraturan perundang-undangan yang berlaku. Adapun bentuk pembinaan kepada warga binaan pemasyarakatan (WBP) adalah berupa pembinaan kepribadian 


\section{EFEKTIVITAS PELAKSANAAN UPAYA PEMBINAAN BAGI NARAPIDANA DI LEMBAGA PEMASYARAKATAN KELAS IIA KARAWANG : Abdul Kholiq}

dan pembinaan kemandirian. Sedangkan upaya pelayanan dilaksanakan sebagaimana telah diketahui oleh seluruh warga binaan pemasyarakatan yang menjadi hak-haknya tersebut, bentuk pelayanannya seperti tempat tidur, makan, minum, pakaian dan lain sebagainya. Yang mana itu semua diberikan oleh para petugas lapas langsung kepada para narapidana". ${ }^{4}$

Berdasarkan pada penjelasan diatas mengenai pelayanan dan perlakuan kepada warga binaan pemasyarakatan dilakukan dengan prosedur yang dituangkan dalam peraturan pemerintah, salah satunya di dalam Peraturan Pemerintah Nomor Peraturan Pemerintah Nomor 32 Tahun 1999 sebagaimana diubah dengan UU Nomor 28 Tahun 2006 tentang Syarat dan Tata Cara Pelaksanaan Hak Warga Binaan Pemasyarakatan. Pelaksanaan pemenuhan hak-hak bagi warga binaan pemasyarakatan atau narapidana yang berdasarkan pada asas persamaan perlakuan dan pelayanan menjadi bagian terpenting bagi petugas lembaga pemasyarakatan (lapas) dalam melaksanakan tugas dan fungsinya.

Bentuk - bentuk pembinaan bagi narapidana diatur dalam Surat Keputusan Menteri Kehakiman No: M.02-PK. 04. 10-1990 sebagaimana yang telah dilakukan petugas Lembaga Pemasyarakatan Kelas IIA Karawang dalam upaya pembinaan terhadap narapidana. Jenis pembinaan tersebut terdiri dari program pembinaan kepribadian dan program pembinaan kemandirian. Adapun tujuan dari kedua program pembinaan tersebut sebagai bekal hidup baik secara materiil dan sprituil.

a) Program Pembinaan Kepribadian

1) Kegiatan olahraga yakni senam kesegaran jasmani, bulu tangkis, tenis meja, futsal, dan bola voly. Kegiatan ini dilaksanakan setiap hari (senin-sabtu).

2) Kegiatan bimbingan kerohanian yakni

\footnotetext{
${ }^{4}$ Hasil wawancara peneliti bersama petugas Lembaga Pemasyarakatan Kelas IIA Karawang
} 
pengajian bulanan,
pengajian yassinan (bagi
agama Islam); bimbingan
kerohanian
Kristen (bagi
agama Kristen);
bimbingan kerohanian
Budha (bagi agama
Budha). Kegiatan ini
dilaksanakan setiap hari
dalam waktu ibadah
masing-masing.

3) Kegiatan kesenian yakni degung, marawis, musik band, kasidahan, organ tunggal, dan tarian. Kegiatan ini dilaksanakan dari hari Senin - Sabtu bergiliran jadwalnya masing-masing tersebut.

4) Kegiatan kesadaran berbangsa dan bernegara yakni kegiatan upacara (apel) bendera. Kegiatan ini dilaksanakan setiap hari Senin pada minggu ketiga.

b) Program Kemandirian

$\begin{array}{lr}\text { 1) Kegiatan } & \text { pelatihan } \\ \text { keterampilan } & \text { yakni }\end{array}$ pelatihan kepramukaan

yang dilaksanakan setiap hari Jumat dan Sabtu.

2) Pendidikan keterampilan minat yakni kegiatan pertanian dengan bercocok tanam dan membudidaya ikan lele di area sekitar Lapas Kelas IIA Karawang.

3) Pendidikan keterampilan kerja yakni membuat kerajinan seni lukis, pahat yang biasa dipamerkan di dalam Lapas. Selain itu, kerajinan tangan lainnya seperti layang-layang, blangkon, kapal-kapalan, konde, wig dan cinderamata lainnya untuk dipasarkan di luar Lapas.

Pembinaan kepribadian harus diikuti oleh semua narapidana tanpa terkecuali, sedangkan pembinaan kemandirian hanya diikuti oleh mereka yang berminat. Dalam ketentuan Lembaga Pemasyarakatan Kelas IIA Karawang, setiap narapidana 
diwajibkan mengikuti paling sedikit satu wujud pembinaan kemandirian yang telah disediakan sesuai dengan minat dan bakatnya. Ketentuan ini diterapkan karena wujud pembinaan kemandirian merupakan bekal hidup bagi narapidana setelah mereka bebas. Apabila narapidana selesai menjalani masa pidana dan kembali ke masyarakat, mereka dapat menggunakan keterampilan yang sudah dilatih di dalam Lapas sebagai mata pencaharian pokok. Oleh karena itu, dengan adanya beberapa bentuk kegiatan pembinaan yang diberikan oleh petugas Lembaga Pemasyarakatan Kelas IIA Karawang terhadap narapidana yang diikuti semua narapidana maka bentuk kegiatan ini berjalan dengan baik dan efektif sebagai bekal narapidana dalam menjalani hidup setelah selesai tinggal di lembaga ini.

\section{B. Kendala yang Terjadi Dalam Pelaksanaan Upaya Pembinaan} Terhadap Narapidana di Lembaga Pemasyarakatan Kelas IIA Karawang

Dalam pelaksanaan pembinaan yang dilakukan oleh petugas Lembaga Pemasyarakatan Kelas IIA Karawang terhadap narapidana sebagaimana telah dijelaskan sebelumnya juga menemukan beberapa hambatan dalam kelancaran proses pelaksanaan pembinaan dalam rangka menyiapkan narapidana untuk kembali menjalani kehidupannya dalam masyarakat (resosialisasi) adalah sebagai berikut :

a) Bidang sumber daya manusia (kepegawaian)

Keterbatasan dan kurangnya tenaga profesional seperti tenaga ahli bidang psikologi, tenaga kesehatan, pengajar dan pelatih keterampilan bagi narapidana dan tidak ada pelatihan khusus mengenai pelaksanaan proses pembinaan serta kurang pemahaman petugas akan arti pentingnya 10 (sepuluh) prinsip Pemasyarakatan dalam 


\section{EFEKTIVITAS PELAKSANAAN UPAYA PEMBINAAN BAGI NARAPIDANA DI LEMBAGA PEMASYARAKATAN KELAS IIA KARAWANG : Abdul Kholiq}

pelaksanaan tugas, sehingga tugas perwalian kurang berjalan secara efektif. Selain itu, hasil wawancara dengan petugas Lapas menemukan kekurang telitian Tim Pengamat Pemasyarakatan dalam mengamati syarat - syarat administratif khususnya mengenai kesesuaian alamat domisili narapidana dengan pihak penjamin dan tempat narapidana menjalani pembinaan tahap akhir, sehingga terdapat surat jaminan yang kurang bisa dipertanggungjawabkan.

b) Bidang administratif

Dalam hal penyusunan dokumen penelitian kemasyarakatan (litmas) yang dilakukan oleh Bapas tidak dibuat secara terperinci dan hanya dalam bentuk yang umum mengenai kondisi keluarga narapidana, pendapat warga sekitar atau tokoh masyarakat setempat. Padahal Litmas tersebut diperlukan sebagai syarat utama dalam pertimbangan oleh Tim Pengamat Pemasyarakatan dalam menentukan kelayakan proses pembinaan narapidana. Selain hal itu, berkas pengusulan surat surat kelengkapan administrasi masih berlangsung lamban, dikarenakan banyaknya pengusulan dari seluruh Lapas di Indonesia yang berpusat di Kantor Direktorat Jenderal Pemasyarakatan yang terletak di Jakarta. Hal ini menyebabkan pelaksanaan tahap pembinaan narapidana mengalami keterlambatan karena menunggu Surat Keputusan dari DirJen Pemasyarakatan.

c) Bidang peraturan perundangundangan (yuridis)

Peraturan dan ketentuan hanya khusus mengatur tentang proses pembinaan beserta tata cara dan prosedur pemberiannya, sedangkan mengenai pengawasan dan pembinaan narapidana yang sedang menjalani pembebasan bersyarat (PB) dan cuti menjelang bebas $(\mathrm{CMB}) \mathrm{di}$ lingkungan masyarakat belum diatur secara rinci dan jelas. 


\section{EFEKTIVITAS PELAKSANAAN UPAYA PEMBINAAN BAGI NARAPIDANA DI LEMBAGA PEMASYARAKATAN KELAS IIA KARAWANG : Abdul Kholiq}

Padahal dalam pelaksanaannya di masyarakat, membutuhkan pengaturan secara jelas agar tujuan pemasyarakatan dapat dipahami dan tercapai.

d) Keterbatasan sarana dan prasarana

Penyediaan lapangan pekerjaan di Lapas sangat tidak sebanding dengan jumlah penghuni (Narapidana) di Lembaga Pemasyarakatan Kelas IIA Karawang, akibatnya tidak semua kepentingan narapidana dapat terakomodir oleh Lapas.

e) Kultur dan masyarakat

Budaya masyarakat yang masih memiliki pandangan negatif dan masih menonjolkan sikap prisonisasi dan stigmatisasi pada narapidana yang masih melekat, khususnya yang sedang menjalani proses pembinaan Pembebasan Bersyarat (PB) atau Cuti menjelang bebas CMB) yang berada di lingkungan masyarakat. Hal tersebut kurang mendukung keberhasilan tujuan pemasyarakatan, bahkan dapat menyebabkan adanya recidive.

f) Kondisi sosial dan ekonomi narapidana

Pembiayaan pengurusan Pembebasan Bersyarat ataupun Cuti Menjelang Bebas dari institusi masih bersifat terbatas dan biaya tambahan harus disediakan oleh pihak narapidana sendiri. Bagi narapidana yang tidak mampu, meskipun sudah memasuki tahap pembinaan dan telah memenuhi syarat sering terbentur dengan permasalahan ekonomi. Dengan demikian, Kondisi sosial dan ekonomi merupakan hambatan utama dalam pelaksanaan proses pembinaan narapidana. Adanya desakan ekonomi dan sosial sangat berpengaruh pada integrasi narapidana di masyarakat. Pengulangan kejahatan sering terjadi pada narapidana yang kurang memiliki kemapanan ekonomi. 


\section{KESIMPULAN}

1. Pelaksanaan upaya pembinaan yang dilakukan oleh Lembaga Pemasyarakatan Kelas IIA Karawang terhadap narapidana telah dilaksanakan sesuai ketentuan perundang - undangan yang berlaku yakni Undang Undang Nomor 12 Tahun 1995 tentang Pemasyarakatan dan Peraturan Pemerintah Nomor 31 Tahun 1999 tentang Pembinaan dan Pembimbingan Warga Binaan Pemasyarakatan. Bentuk kegiatan yang diberikan terdiri dari program pembinaan kepribadian yang terdiri dari kegiatan olahraga, kerohania, kesenian dan kegiatan kesadaran berbangsa dan bernegara. Selanjutnya program pembinaan kemandirian yang terdiri dari kegiatan pelatihan keterampilan minat dan keterampilan kerja bagi narapidana.

2. Hambatan atau kendala yang ditemukan dalam pelaksanaan pembinaan terhadap narapidana oleh petugas Lembaga
Pemasyarakatan Kelas IIA Karawang diantaranya bidang sumber daya manusia (kepeawaian yang profesional), bidang administratif, bidang peraturan perundang-undangan (yuridis), bidang sarana dan prasarana, kultur dan masyarakat, kondisi sosial dan ekonomi narapidana. Dengan adanya beberapa temuan sebagai hambatan dalam pelaksanan pembinaan terhadap narapidana, maka peneliti berpadangan bahwa proses pembinaan yang dilaksanakan oleh petugas Lembaga Pemasyarakatan Kelas IIA Karawang belum berjalan secara efektif.

\section{DAFTAR PUSTAKA}

\section{A. Buku}

Ashofa, Burhan, 2007, Metode Penelitian Hukum, Jakarta : Rineka Cipta

Harsono, C.I., 1995, Sistem Baru Pembinaan Narapidana, Jakarta: Djambatan 
Marlina, 2011, Hukum Penitensier,

Bandung : Refika Aditama

Priyatno, Dwidja, 2013, Sistem

Pelaksanaan Pidana Penjara

Di Indonesia, Bandung :

Refika Aditama

Siagi, Sondang, 1991, Filsafat

Administrasi, Jakarta :

Gunung Agung

Soekanto, Soerjono, 1985, Efektivitas

Hukum dan Peranan Saksi,

Bandung : Remaja Karya

\section{B. Peraturan Perundang - undangan}

Undang - Undang Nomor 12 Tahun

195 tentang Pemasyarakatan

Peraturan Pemerintah Nomor 31 Tahun

1999 tentang Pembinaan dan

Pembimbingan Warga Binaan

Pemasyarakatan 